\title{
MEDIA CORROSIVENESS AND MATERIALS RESISTANCE AT PRESENCE OF AGGRESSIVE CARBON DIOXIDE
}

\author{
R. R. Kantyukov, D. N. Zapevalov, R. K. Vagapov
}

Scientific-Research Institute of Natural Gases and Gas Technologies - “Gazprom VNIIGAZ” (Razvilka Village, Moscow Region 142717, Russian Federation)

Abstract. At the present stage of gas field development, the products of many mining facilities have increased content of corrosive $\mathrm{CO}_{2}$. The corrosive effect of $\mathrm{CO}_{2}$ on steel equipment and pipelines is determined by the conditions of its use. $\mathrm{CO}_{2}$ has a potentially wide range of usage at oil and gas facilities for solving technological problems (during production, transportation, storage, etc.). Simulation tests and analysis were carried out to assess the corrosion effect of $\mathrm{CO}_{2}$ on typical steels (carbon, low-alloy and alloyed) used at field facilities. Gas production facilities demonstrate several corrosion formation zones: lower part of the pipe (when moisture accumulates) and top of the pipe (in case of moisture condensation). The authors have analyzed the main factors influencing the intensity of carbon dioxide corrosion processes at hydrocarbon production with $\mathrm{CO}_{2}$, its storage and use for various technological purposes. The main mechanism for development of carbon dioxide corrosion is presence/condensation of moisture, which triggers the corrosion process, including the formation of local defects (pits, etc.). X-ray diffraction was used for the analysis of corrosion products formed on the steel surface, which can have different protective characteristics depending on the phase state (amorphous or crystalline).

Keywords: oil and gas facilities, carbon dioxide, media corrosiveness, carbon dioxide corrosion, corrosion rate

For citation: Kantyukov R.R., Zapevalov D.N., Vagapov R.K. Media corrosiveness and materials resistance at presence of aggressive carbon dioxide. Izvestiya. Ferrous Metallurgy. 2021, vol. 64, no. 11, pp. 793-801. (In Russ.). https://doi.org/10.17073/0368-0797-2021-11-793-801

\section{оригинальная статья ИССЛЕДОВАНИЕ КОРРОЗИОННОЙ АКТИВНОСТИ СРЕД И СТОЙКОСТИ ИСПОЛЬЗУЕМЫХ МАТЕРИАЛОВ В УСЛОВИЯХ ПРИСУТСТВИЯ АГРЕССИВНОГО ДИОКСИДА УГЛЕРОДА}

\author{
Р. Р. Кантюков, Д. Н. Запевалов, Р. К. Вагапов
}

Научно-исследовательский институт природных газов и газовых технологий - Газпром ВНИИГАЗ (Россия, 142717 , Московская область, п. Развилка)

\begin{abstract}
Аннотация. На современном этапе развития газовых месторождений в продукции многих объектов добычи газа присутствуют повышенные содержания коррозионно-агрессивного $\mathrm{CO}_{2}$. Коррозионное воздействие $\mathrm{CO}_{2}$ на стальное оборудование и трубопроводы определяется условиями его использования. Диоксид углерода имеет потенциально широкий спектр использования на нефтегазовых объектах для решения технологических задач (при добыче, транспортировке, хранении и др.). Выполнены имитационные испытания и проведены исследования по оценке коррозионного влияния $\mathrm{CO}_{2}$ на типичные стали (углеродистые, низколегированные и легированные), применяемые на промысловых объектах. Проанализированы основные факторы, влияющие на интенсивность процессов углекислотной коррозии в условиях добычи, хранения и использования углеводородов с $\mathrm{CO}_{2}$ для различных технологических целей. Основным механизмом развития углекислотной коррозии является присутствие/конденсация влаги, которая запускает процесс коррозии, в том числе с образованием локальных дефектов (питтингов и др.).
\end{abstract}

Ключевые слова: нефтегазовые объекты, диоксид углерода, коррозионная агрессивность среды, углекислотная коррозия, скорость коррозии

Для цитирования: Кантюков Р.Р., Запевалов Д.Н., Вагапов Р.К. Исследование коррозионной активности сред и стойкости используемых материалов в условиях присутствия агрессивного диоксида углерода // Известия вузов. Черная металлургия. 2021. Т. 64. № 11. С. 793-801. https://doi.org/10.17073/0368-0797-2021-11-793-801

In recent years, the problem of carbon dioxide corrosion (CDC) in gas fields has become relevant. In the Russian Federation in recent years at a number of gas facilities, problems of corrosive nature have arisen due to the increased content of carbon dioxide in the produced pro- ducts [1]. Taking into account corrosion risks (including due to the CDC) plays an important role in the processes of ensuring the reliable and safe operation of enterprises for hydrocarbons extraction [2-3]. To control the technical condition of gas production and underground storage 
facilities, a set of measures is used, including diagnostic surveys and corrosion monitoring [4].

Carbon dioxide $\left(\mathrm{CO}_{2}\right)$ can be in several states of aggregation: gas, liquid and supercritical (SCS). The so-called "triple point" connects all three states of $\mathrm{CO}_{2}\left(P_{\text {cr. }}=7.38 \mathrm{MPa}\right.$ and $T_{\text {cr. }}=31.1^{\circ} \mathrm{C}$ ), depending on change on which the type of aggregate state is determined.

At gas production facilities, the partial pressure is relatively low, and $\mathrm{CO}_{2}$ is in gaseous aggregate state. It should be noted that $\mathrm{CO}_{2}$ is not only a component in the composition of produced products, but can also be used at oil and gas facilities for technological tasks. In this case, the above-mentioned special properties of $\mathrm{CO}_{2}$ can be effectively used, including in SCS. Among the most commonly used are the use of $\mathrm{CO}_{2}$ to intensify oil or gas production at the later stages of field exploitation and as a buffer gas in underground gas storage (UGS) facilities [5]. It should be also mentioned about the injection of excess $\mathrm{CO}_{2}$ into underground storage facilities in order to reduce its emissions into the environment [ $6-7]$. For these purposes, both the infrastructure for pumping gas into underground reservoirs and pipelines for transporting it from the places of $\mathrm{CO}_{2}$ separation to the disposal site are being arranged [8]. For such purposes, underground caverns are used after the end of the exploitation of oil or gas fields, geological cavities with aquifers [9-10].

In all of the above cases, aggressive $\mathrm{CO}_{2}$ comes into contact with steel equipment and pipeline systems, which in the presence of an aqueous phase and other factors intensifying corrosion (temperature, etc.) can lead to the development of corrosion damage. In the first place, the most dangerous forms of local defects typical for CDC will develop. In this regard, the article discusses topical issues of assessing the corrosiveness of carbon dioxide media and the resistance of various steels in the conditions of $\mathrm{CDC}$ at oil and gas facilities.

\section{RESEARCH METHODS}

Corrosion tests under conditions of moisture condensation were carried out at normal $\left(20-25^{\circ} \mathrm{C}\right)$ temperature. Test methods for moisture condensation, sample processing, assessment of corrosion defects, and statistical data processing were carried out according to the previously described procedures [11]. After testing, the following was determined: general corrosion rate $K_{\text {gen }}$ by the sample weight loss; rate of local corrosion in terms of the depth of corrosion damage (average $K_{\text {loc aver }}$ - by averaging over all local defects, maximum $K_{\text {loc. max }}-$ by the deepest local damage).

Corrosion tests were carried out using the gravimetric method. Effect of the partial pressure of corrosive gases on corrosion rate of the samples was evaluated in an autoclave unit (static conditions), after oxygen was removed by blowing with an inert gas. The exposure time of gravimetric samples in an autoclave unit was 120 hours.
The phase composition of corrosion products was analyzed by X-ray diffraction, which is based on recording the dependence of the intensity of X-ray reflection by compounds crystal lattices on the value of diffraction angle, followed by the diffraction pattern interpretation. The survey was carried out on ARL X'TRA X-ray diffractometer. The identification of crystalline phases was carried out by comparing the array of reflections obtained from the test sample with the reference diffraction patterns of individual compounds contained in the international database of diffraction standards.

During the tests, carbon steel grades St20 and Kh65 were used.

\section{RESULTS AND DISCUSSION}

Let us consider the corrosiveness of the medium of gas production facilities in conditions of increased $\mathrm{CO}_{2}$ content. The analysis shows that the most corrosive type of equipment at gas production facilities are downhole equipment and field pipelines. Under such conditions, corrosion can occur [12]:

- at the pipe bottom when moisture accumulates (bottom-of-line corrosion, BOL corrosion);

- at the pipe top in case of moisture condensation (topof-line corrosion, TOL corrosion);

- in places where moisture accumulates (cracks, gaps, stagnant zones, elevation differences, etc.).

The main condition for corrosion process development is the presence of moisture when reactions of its interaction with steel in the solution volume (BOL) or in a thin film of moisture on steel (TOL) occur. TOL corrosion in contrast to the corrosive conditions of oil facilities is typical for gas fields. When leaving the well, water vapor in the gas phase condenses on the pipe inner surface due to the temperature difference between the wet gas flow and the environment, which leads to the appearance and TOL corrosion development. BOL corrosion will be typical in sections of the pipeline system when the water phase is in constant contact/movement with the inner surface of the pipeline steel [13 - 14].

Results of the autoclave tests (Table 1) show that with an increase in $\mathrm{CO}_{2}$ partial pressure the corrosion rate of steel St20 mainly grows, as well as with an increase in temperature. It should be borne in mind that with an increase in temperature deposits can form including the form of corrosion products. The resulting solid sediments (iron carbonates, etc.) at $80-90^{\circ} \mathrm{C}$ may have certain protective properties, because they form more tightly packed than at lower temperatures. Probably, it is precisely with this that the fact that at $80-90{ }^{\circ} \mathrm{C}$ is not observed a stronger increase, as in other types of corrosion, increase in the rate of CDC. This test simulates BOL corrosion conditions.

Our TOL tests in the presence of $\mathrm{CO}_{2}$ showed that at a low (less than $0.1 \mathrm{~mm} /$ year) rate of general corrosion, carbon steel X65 (API 5L) undergoes severe lo- 
IzVestiya. Ferrous Metallurgy. 2021, vol. 64, no. 11, pp. 793-801.

(C) 2021. Kantyukov R.R., Zapevalov D.N., Vagapov R.K. Media corrosiveness and materials resistance at presence of aggressive carbon dioxide

Table 1

General corrosion rate ( $\mathrm{mm} / \mathrm{year})$ of steel $\mathrm{St} 20$ according to the results of autoclave tests

Таблица 1. Скорость общей коррозии (мм/год) стали Ст20 по результатам автоклавных испытаний

\begin{tabular}{|c|c|c|c|c|c|c|c|c|}
\hline \multirow{3}{*}{$\begin{array}{l}\text { Partial pressure } \\
\qquad \mathrm{CO}_{2}, \mathrm{MPa}\end{array}$} & \multicolumn{8}{|c|}{ Temperature and mineralization of the aquatic environment, ${ }^{\circ} \mathrm{C}$} \\
\hline & \multicolumn{2}{|c|}{30} & \multicolumn{2}{|c|}{60} & \multicolumn{2}{|c|}{80} & \multicolumn{2}{|c|}{90} \\
\hline & $3 \% \mathrm{NaCl}$ & $0.5 \% \mathrm{NaCl}$ & $3 \% \mathrm{NaCl}$ & $0.5 \% \mathrm{NaCl}$ & $3 \% \mathrm{NaCl}$ & $0.5 \% \mathrm{NaCl}$ & $3 \% \mathrm{NaCl}$ & $0.5 \% \mathrm{NaCl}$ \\
\hline 0 & 0.073 & 0.065 & 0.063 & 0.065 & 0.120 & 0.093 & 0.108 & 0.108 \\
\hline 1 & 0.221 & 0.203 & 0.241 & 0.240 & 0.522 & 0.338 & 0.490 & 0.476 \\
\hline 4 & 0.201 & 0.196 & 0.365 & 0.331 & 0.590 & 0.539 & 0.553 & 0.556 \\
\hline
\end{tabular}

cal corrosion (Table 2). Particularly high local corrosion $(0.5-1.5 \mathrm{~mm} /$ year) is observed on samples from the weld zone, which is several times higher than that of the base metal. It is the welds that can be more susceptible to uneven types of corrosion damage. During heat treatment of the metal (welding), a change in the composition and properties of the material can occur, which can lead to the emergence of inhomogeneities (heterogeneity) between the pipe base metal and the weld and that can cause a corrosion process.

The tests carried out under the conditions of moisture condensation, characteristic of TOL corrosion, showed [11] that there is also a tendency to an increase in the rate of local corrosion with an increase in $\mathrm{CO}_{2}$ partial pressure. The corrosion process in a condensed moisture film for the tested steels was characterized by localization of corrosion damage in the form of multiple pits on the surface of metal samples [12]. An increase in $\mathrm{CO}_{2}$ pressure will increase the solubility of the gas in aqueous phase, causing an increase in the corrosion rate.

With an increase in the temperature of the test medium from $20-25$ to $50{ }^{\circ} \mathrm{C}$, an increase in both general and local corrosion in the vapor phase is observed. Such an increase in $\mathrm{CO}_{2}$ corrosive effect is associated not so much with the

thermodynamic enhancement of coupled electrochemical corrosion processes, which can also take place, but, to a greater extent, is explained by an increase in the amount of moisture condensed on the steel surface. This is due to a large temperature gradient between the surface of steel samples, which are forcibly cooled (up to $15^{\circ} \mathrm{C}$ ) to create conditions for moisture condensation, and an increased temperature of the gaseous medium with $\mathrm{CO}_{2}$ inside the test cell. It is known that for the development of CDC, including TOL corrosion, a sufficiently large amount of water is required in comparison with other types of corrosion, for example, with hydrogen sulfide corrosion [13-14]. The development of local corrosion in the vapor phase is associated with moisture condensation: with a lack of air humidity, the dew point will not be reached and the moisture film will not precipitate on the steel surface. According to the previously obtained data [15], at $33 \%$ and $66 \%$ air humidity, the moisture content was insufficient to localize corrosion in the presence of $\mathrm{CO}_{2}$ during TOL corrosion. But as soon as the humidity increased and reached higher values, for example, $100 \%$, and the dew point was reached in the test cell, then the development of the local CDC began, the rate of which reached up to $1-2 \mathrm{~mm} /$ year. The presence of moisture is important for the development of CDC pro-

Table 2

Results of the tests on local corrosion rates calculated by the average $\left(K_{l o c}\right)$ and maximum $\left(K_{\text {loc.max }}\right)$ depth of corrosion damage on steel $\mathrm{X} 65$ in $\mathrm{CO}_{2}$ medium and moisture condensation

Таблица 2. Результаты испытаний по определению локальных скоростей коррозии, рассчитанных по средней (K $\left.\boldsymbol{K}_{\text {лок }}\right)$ и максимальной $\left(K_{\text {лок.макс }}\right)$ глубине коррозионных повреждений на стали Х65 в среде СО, и конденсации влаги

\begin{tabular}{c|c|c|c|c|c}
\hline \multirow{2}{*}{$\begin{array}{c}\text { Type of } \\
\text { sample }\end{array}$} & \multirow{2}{*}{$\begin{array}{c}\text { Number } \\
\text { of sample }\end{array}$} & \multirow{2}{*}{$\begin{array}{c}\text { Depth of corrosion } \\
\text { damage, } \mu \mathrm{m}\end{array}$} & \multicolumn{3}{|c}{ Corrosion rate, mm/year } \\
\cline { 3 - 6 } & & average & local (depth of corrosion damage) \\
\hline \multirow{3}{*}{ Base metal } & 1 & $24 / 27$ & 0.0643 & 0.269 & $K_{\text {loc. max }}$ \\
\cline { 2 - 6 } & 2 & $22 / 35$ & 0.0459 & 0.241 & 0.299 \\
\cline { 2 - 6 } & 3 & $19 / 24$ & 0.0756 & 0.210 & 0.387 \\
\hline \multirow{3}{*}{ Weld } & 4 & $44 / 78$ & 0.0889 & 0.489 & 0.265 \\
\cline { 2 - 6 } & 5 & $64 / 132$ & 0.0885 & 0.703 & 1.460 \\
\hline & 6 & $56 / 142$ & 0.0668 & 0.622 & 1.571 \\
\hline
\end{tabular}


cesses not only for gaseous, but also for other aggregate states of $\mathrm{CO}_{2}$. According to [16], for each of the aggregate states of $\mathrm{CO}_{2}$ there is a critical value of water content for the beginning of corrosion localization: $80 \%$ humidity for gas; $60 \%$ - for liquid and SCS. The authors carried out the tests on steel X65 at $25-35^{\circ} \mathrm{C}$ and increased values of $\mathrm{CO}_{2}$ pressure $(4-8 \mathrm{MPa})$.

Analysis of the effect of various salts (in low concentration) showed that they insignificantly affect the corrosion rate in the vapor phase [17]. An increase in the rate of localized corrosion will be influenced by an increase in water content in the test chamber, which will remain approximately the same when the mineral composition changes and the medium mineralization remains unchanged. An increase in local corrosion is possible only if, as a result of the dissociation of salt in water, its acidification and/or the formation of acid gases occurs.

The test results confirm that gas facilities operated in conditions of $\mathrm{CO}_{2}$ presence in the extracted products are subject to increased corrosion hazard in the water and vapor phases, especially to local corrosion typical for CDC.

Corrosion products formed on the metal surface play a certain role in the protection of steels from corrosion. Tests carried out in an aqueous medium (Figure $a$ ) to determine the phase composition of the film formed on steel after autoclave tests showed that siderite $\left(\mathrm{FeCO}_{3}\right)$ is formed predominantly during $\mathrm{CDC}$, and mackinawite $(\mathrm{FeS})$ can form in the presence of hydrogen sulfide impurities, both independently and together with $\mathrm{FeCO}_{3}$.

In addition to the amount of $\mathrm{CO}_{2}, \mathrm{CDC}$ in the aqueous environment is influenced by its mineral composition. UGS facilities and $\mathrm{CO}_{2}$ storage sites are often located in aquifers [18]. The authors of [19] provide data on the effect of saline water and its composition (up to $35,000 \mathrm{ppm} \mathrm{Cl}^{-}$, $10,000 \mathrm{ppm} \mathrm{Ca}^{2+}$ and $\left.10,000 \mathrm{ppm} \mathrm{Mg}^{2+}\right)$ on the corrosion resistance of steel X65 $(0.11 \% \mathrm{Cr})$ in the conditions of SCS corrosive gas formation. Simulation tests were carried out in an aqueous electrolyte saturated with $\mathrm{CO}_{2}\left(60^{\circ} \mathrm{C}\right.$, $10 \mathrm{MPa})$. The main initiator of corrosion localization was the presence of chloride anions in water which contribute to the formation of iron carbonate (in the form of deposits of corrosion products). The addition of $\mathrm{Ca}^{2+}$ and $\mathrm{Mg}^{2+}$ has a different effect on the properties of corrosion deposits, their morphology and coprecipitation together with iron carbonate on steel. The resulting local corrosion defects had a depth of $20-50 \mu \mathrm{m}$.

As in our tests (Figure $a$ ) at a $\mathrm{CO}_{2}$ pressure of $0.8 \mathrm{MPa}$, in the study [20], siderite was obtained in a $\mathrm{NaCl}$ solution at $80{ }^{\circ} \mathrm{C}$ saturated with $\mathrm{CO}_{2}$ (but at a higher pressure of $15 \mathrm{MPa}$ ). However, with the addition of other salts, for example, $\mathrm{CaCO}_{3}$, the layer of corrosion products turned out to be more porous and less resistant to chloride anions, which provoke the nucleation and development of pits, in contrast to the denser siderite layer.
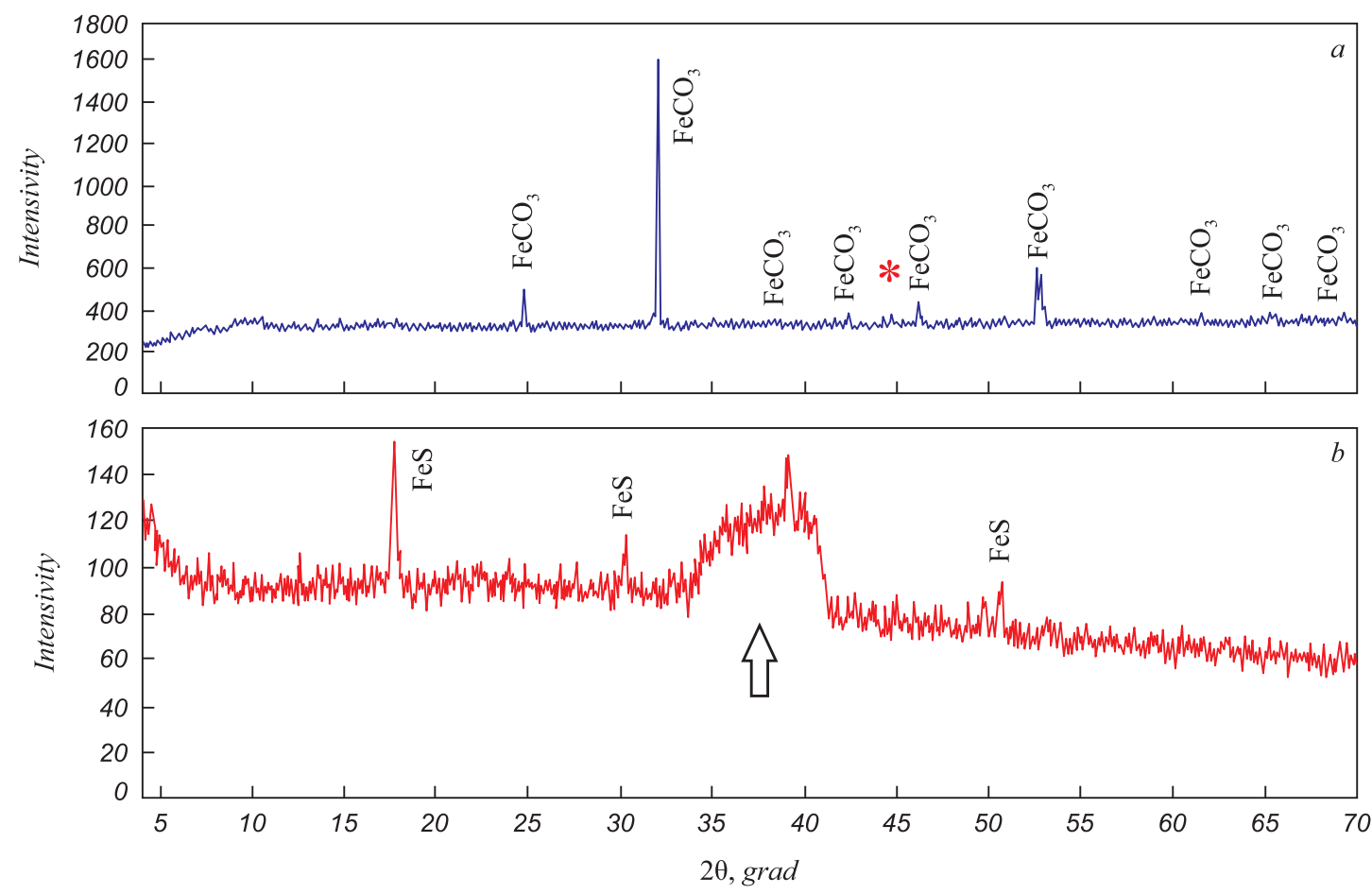

Identified experimental diffraction pattern of corrosion products after autoclave tests on steel X65:

$a-P_{\mathrm{CO}_{2}}=0.8 \mathrm{MPa}$, temperature $80{ }^{\circ} \mathrm{C}, 3 \% \mathrm{NaCl} ; b-P_{\mathrm{H}_{2} \mathrm{~S}}=0.15 \mathrm{MPa}$, temperature $60^{\circ} \mathrm{C}$, salinity of the water phase $1 \mathrm{~g} / 1$ (arrow indicates an X-ray amorphous gallo, asterisk indicates X65 steel signal)

Идентифицированная экспериментальная дифрактограмма продуктов коррозии, полученных после автоклавных испытаний на стали Х65: $a-P_{\mathrm{CO}_{2}}=0,8 \mathrm{MПа,} \mathrm{температура} 80^{\circ} \mathrm{C}, 3 \% \mathrm{NaCl} ; b-P_{\mathrm{H}_{2} \mathrm{~S}}=0,15 \mathrm{MПа}$, температура $60{ }^{\circ} \mathrm{C}$, минерализация водной фазы 1 г/л (стрелкой указано рентгеноаморфное галло, звездочкой - сигнал от стали Х65) 
Tests of carbon steel $\mathrm{X} 65$ at $25-60^{\circ} \mathrm{C}$ and a pressure of $2.0-14.5 \mathrm{MPa}$ showed [21] that the corrosion rate at first can reach up to $28 \mathrm{~mm} / \mathrm{year}$, then decreasing to $1 \mathrm{~mm} /$ year. The formation of corrosion products can inhibit the corrosion process over time, but their protective properties will depend on the temperature of the environment. At higher temperatures, denser and less porous films were formed, mainly consisting of siderite. The steel surface also plays a role: presence of cementite at the interface led to formation of loose films of corrosion products.

The temperature factor can also intensify the corrosion processes. Investigation of the effect of temperature $\left(35^{\circ} \mathrm{C}\right.$ and $\left.50{ }^{\circ} \mathrm{C}\right)$ at $\left.\mathrm{SCS}(8 \mathrm{MPa} \mathrm{CO})_{2}\right)$ for steel X65 $(0.11 \% \mathrm{Cr})$ showed [22] that the development of local defects is observed: the rate of local corrosion can reach $0.3-0.9 \mathrm{~mm} /$ year (at $35^{\circ} \mathrm{C}$ ), increasing to $0.9-1.7 \mathrm{~mm} /$ year (at $50^{\circ} \mathrm{C}$ ). It is also noted that an increase in local corrosion occurs with an increase in the amount of water.

An important role in the corrosiveness of $\mathrm{CO}_{2}$, both in the gas and in SCS, is played by the presence of impurities in it, such as $\mathrm{SO}_{2}, \mathrm{H}_{2} \mathrm{~S}$, etc.

TOL corrosion tests in a $\mathrm{CO}_{2}$ environment with small additions of $\mathrm{H}_{2} \mathrm{~S}(50 \mathrm{ppm}$ ) on steel X65 showed (Table 3) that the local corrosion rate reaches $0.90-1.37 \mathrm{~mm} /$ year. On the samples, pits are observed, up to $50-100 \mu \mathrm{m}$ in depth, which were formed during 30 days of the test. Dif- ference in the rate of local corrosion, which was at CDC (Table 2), is leveled in the presence of $\mathrm{H}_{2} \mathrm{~S}$. This is apparently due to the higher corrosivity of $\mathrm{H}_{2} \mathrm{~S}$ compared to $\mathrm{CO}_{2}$.

It is also noted in [23] that even small additions of $\mathrm{H}_{2} \mathrm{~S}$ (21 ppm) to the aqueous $\mathrm{CO}_{2}$ medium lead to a change in the corrosion mechanism from carbon dioxide to hydrogen sulfide. In this case, composition of the corrosion products also changes: only mackinawite is formed on the steel (without traces of siderite). According to the authors, the formed FeS film on steel X65 is not capable of being a barrier to the penetration of corrosive components to the steel surface. This may be due to the small thickness of FeS layer which directly depends on $\mathrm{H}_{2} \mathrm{~S}$ content. According to the results of the autoclave tests in an aqueous $\mathrm{H}_{2} \mathrm{~S}$-containing medium (Figure $b$ ), mackinawite crystals were also found on steel X65, but their content does not exceed $40 \%$. The diffractogram shows that there is an X-ray amorphous gal10 : the content of amorphous compounds reaches $60 \%$. The morphology of mackinawite (density, absence/presence of pores), as well as its thickness, will affect the barrier properties of the formed corrosion products in relation to $\mathrm{H}_{2} \mathrm{~S}$ corrosion. Fully crystallized substances will form a more densely packed film of corrosion products.

In [24], results of the studies at a temperature of $35^{\circ} \mathrm{C}$ and in SCS $\left(8 \mathrm{MPa} \mathrm{CO}_{2}\right)$ for steels X65 $(0.11 \% \mathrm{Cr})$ and

\section{Corrosion rates, depth of defects and appearance of steel X65 samples after removal of corrosion products and testing in $\mathrm{CO}_{2}$ medium with addition of $50 \mathrm{ppm} \mathrm{H}_{2} \mathrm{~S}$}

Таблица 3. Скорости коррозии, глубина дефектов и внешний вид образцов стали Х65 после удаления продуктов коррозии и испытаний в среде $\mathrm{CO}_{2}$ с добавлением 50 ppm $\mathrm{H}_{2} \mathrm{~S}$

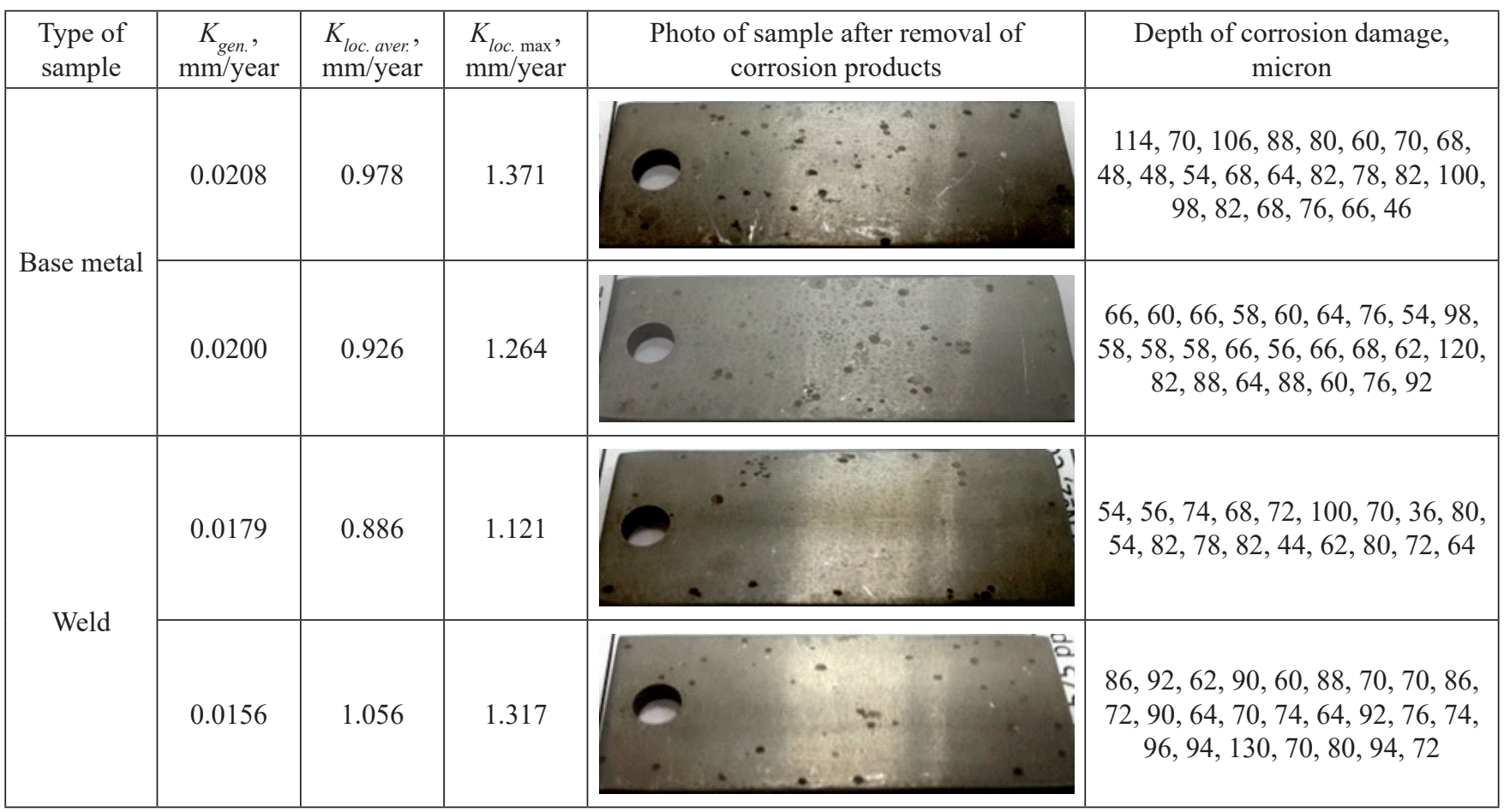


$13 \mathrm{Cr}(13 \% \mathrm{Cr})$ are given. The addition of two other aggressive gases $\left(\mathrm{SO}_{2}\right.$ and $\left.\mathrm{O}_{2}\right)$ to $\mathrm{CO}_{2}$ in the presence of moisture leads to a synergistic effect in corrosion process development. The general corrosion rate for both steels is equally high: $0.95 \mathrm{~mm} /$ year for X65 steel, and $0.65 \mathrm{~mm} /$ year for $13 \mathrm{Cr}$ steel. Pitting corrosion is even higher for both steels (X65 and 13Cr), and ranges from 7 to $80 \mathrm{~mm} /$ year. The presence of impurities leads to the formation of other corrosion products: iron oxides and iron sulfate instead of iron carbonate. Dissolution of $\mathrm{SO}_{2}$ in an aqueous film leads to the formation of extremely corrosive sulfuric acid, the destructive effect of which is enhanced by the presence of a strong oxidizing agent in the form of $\mathrm{O}_{2}$.

The presence of sulfur compounds $\left(\mathrm{SO}_{2}, \mathrm{H}_{2} \mathrm{~S}\right)$ even in small trace amounts, negatively affects the corrosive situation in CDC, enhancing its development.

The use of high-alloy steels (with a high chromium content for corrosion protection) is not always able to provide protection against CDC. Tests of carbon (X65) and alloyed $(13 \mathrm{Cr})$ steels showed that at a temperature of $80^{\circ} \mathrm{C}$ and high $\mathrm{CO}_{2}$ pressure $(13.5 \mathrm{MPa})$ the local corrosion rate can reach 15.6 and $0.32 \mathrm{~mm} /$ year, respectively [25]. Another work [26] provides comparative test results for similar steels X65, C75 and X20Cr13 in an aqueous medium saturated with $\mathrm{SCS} \mathrm{CO}_{2}$ at elevated temperatures $\left(50-130{ }^{\circ} \mathrm{C}\right)$ and $\mathrm{CO}_{2}$ pressure $(9.5-21.5 \mathrm{MPa})$. The general corrosion rate for carbon steels (C75 and $\mathrm{X} 65)$ reached $3.5-15 \mathrm{~mm} /$ year, local defects were observed on the metal surface. In corrosion-resistant steel X20Cr13, the general corrosion rate reaches $0.3-0.8 \mathrm{~mm} /$ year (there were no local defects). According to [27], in the presence of impurity gases in $\mathrm{CO}_{2}$ in $\mathrm{SCS}$, chloride anions from the aqueous medium play an important role in formation and development of local defects on alloyed steel $13 \mathrm{Cr}$, which locally destroy the film of corrosion products.

In such aggressive conditions, high-alloy steels can be used for the protection of steel equipment and pipelines which, however, in some particularly aggressive conditions also require the use of anti-corrosion protection means [28]. Carbon and low-alloy steels that are not resistant to CDC, as well as some alloyed ones, can be protected by corrosion inhibitors or coatings.

On carbon or low-alloy steels at $80^{\circ} \mathrm{C}$ and $12 \mathrm{MPa} \mathrm{CO}_{2}$ in the presence of inhibitors, the corrosion rate can decrease to $0.1 \mathrm{~mm} /$ year [29]. A decrease in corrosion tenfold compared to background values is observed. Although the initial background corrosion rate on low alloy steels is lower than on carbon steels, the inhibitor protects carbon steels better than low-alloy steels. This is explained by the morphology of corrosion products: on low-alloy steels they are thicker and more porous, which can negatively affect the adsorption of corrosion inhibitor

Somewhat different results were shown by tests of a number of $\mathrm{CDC}$ inhibitors in an aqueous medium saturated with $\mathrm{SCS} \mathrm{CO}_{2}$ at elevated temperatures $\left(50-130{ }^{\circ} \mathrm{C}\right)$ and $\mathrm{CO}_{2}$ pressure $(9.5-21.5 \mathrm{MPa})$ [26]. These conditions are more aggressive and, apparently, it is precisely with this that the use of inhibitors for carbon steels, although it leads to a significant decrease in corrosion rate, it does not fall below $1 \mathrm{~mm} /$ year: increased temperature conditions lead to a higher corrosive influence of environments on carbon steels (X65 and C75). Reagents more effectively inhibit CDC on alloyed $\mathrm{X} 20 \mathrm{Cr} 13$ steel, reducing it below $0.1 \mathrm{~mm} /$ year.

Tests of carbon steel at $50{ }^{\circ} \mathrm{C}$ and $10 \mathrm{MPa}$ showed [30] that in the vapor phase over $5 \% \mathrm{NaCl}$ the corrosion rate is $0.06 \mathrm{~mm} /$ year, and in the water phase $-0.62 \mathrm{~mm} /$ year. When $\mathrm{SO}_{2}$ is added to this system, the corrosion rate increases by $5-14$ times to 3.6 and $8.2 \mathrm{~mm} /$ year for the vapor and water phases, respectively. Tests of 3 inhibitors have confirmed that they are capable of protecting steel in such aggressive environments: the corrosion rate decreases to $0.13-0.18 \mathrm{~mm} / \mathrm{year}$, and for the most effective to $0.07-0.09 \mathrm{~mm} / \mathrm{year}$.

Coatings can also be used for CDC protection. In [31], the possibility of using conversion coatings of a complex composition for the protection of pipelines transporting $\mathrm{CO}_{2}$, including under conditions of acidification of the aqueous phase, is discussed. It is important for coatings to be non-porous. The authors of [32] report the use of a metal microstructured $\mathrm{Ni}-\mathrm{Co}$ coating with corrosion resistance for protection in $\mathrm{CO}_{2}$ conditions.

\section{CONCLUSIONS}

Analysis of the research results shows that when $\mathrm{CO}_{2}$ is used, both in gas and SCS, the main corrosion factors will be the possibility of moisture condensation and the dissolution of $\mathrm{CO}_{2}$ in which will trigger the $\mathrm{CDC}$ mechanism. To investigate such corrosion cases, it is important to exhibit TOL corrosion tests. The presence of impurity gases will affect the acceleration of corrosion process. An important factor of the protective effect is phase composition and morphology of corrosion products. Corrosion inhibitors and coatings can be used to protect steel against corrosion in the presence of $\mathrm{CO}_{2}$ (in various states of aggregation).

\section{REFERENCES СПИСОК ЛИТЕРАTУРЫ}

1. Zapevalov D., Vagapov R. Possibilities and limitations of the organization of anticorrosion protection at gas production facilities. E3S Web of Conferences. 2021, vol. 225, article 03002. http://doi.org/10.1051/e3sconf/202122503002

2. Kantyukov R.R., Zapevalov D.N., Vagapov R.K. Hazard assessment of internal carbon dioxide corrosion of field pipelines at gas and
1. Zapevalov D., Vagapov R. Possibilities and limitations of the organization of anticorrosion protection at gas production facilities // E3S Web of Conferences. 2021. Vol. 225. Article 03002. http://doi.org/10.1051/e3sconf/202122503002

2. Кантюков Р.Р., Запевалов Д.Н., Вагапов Р.К. Оценка опасности внутренней углекислотной коррозии промысловых трубопрово- 
gas condensate fields. Bezopasnost' truda v promyshlennosti. 2021, no. 2, pp. 56-62. (In Russ.).

3. Yaro A.S., Abdul-Khalik K.R., Khadom A.A. Effect of $\mathrm{CO}_{2}$ corrosion behavior of mild steel in oilfield produced water. Journal of Loss Prevention in the Process Industries. 2015, vol. 38, pp. 24-38. https://doi.org/10.1016/j.jlp.2015.08.003

4. Aslanyan A.M., Aslanyan I.Yu., Kantyukov R.R., etc. Implementation of advanced passive acoustics hardware and software complex for well integrity diagnostics. Bezopasnost' truda v promyshlennosti. 2020, no. 11, pp. 56-62. (In Russ.).

5. Ryazantsev M.V., Lozin E.V. Carbon dioxide flooding: history of world and local investigations. OIJ. 2020, no. 7, pp. 100-103. (In Russ.). https://doi.org/10.24887/0028-2448-2020-7-100-103

6. Il'inova A.A., Romasheva N.V., Stroikov G.A. Prospects and social effects of carbon dioxide sequestration and utilization projects. $\mathrm{Za}$ piski Gornogo Instituta. 2020, vol. 244, pp. 493-502. (In Russ.).

7. Khan S.A. The analysis of world projects on catching and burial place of carbonic gas. Georesursy. 2010, no. 4(36), pp. 55-62. (In Russ.).

8. Onyebuchi V.E., Kolios A., Hanak D.P., etc. A systematic review of key challenges of $\mathrm{CO}_{2}$ transport via pipelines. Renewable and Sustainable Energy Reviews. 2018, vol. 81, part 2, pp. 2563-2583. https://doi.org/10.1016/j.rser.2017.06.064

9. He M., Luis S., Rita S., Ana G., Eurípedes V.Jr., Zhang N. Risk assessment of $\mathrm{CO}_{2}$ injection processes and storage in carboniferous formations: A review. Journal of Rock Mechanics and Geotechnical Engineering. 2011, vol. 3, no. 1, pp. 39-56. https://doi.org/10.3724/SP.J.1235.2011.00039

10. Choi Y.-S., Young D., Nešić S., Gray L.G.S. Wellbore integrity and corrosion of carbon steel in $\mathrm{CO}_{2}$ geologic storage environments: A literature review. International Journal of Greenhouse Gas Control. 2013, vol. 16S, pp. S70-S77. https://doi.org/10.1016/j.ijggc.2012.12.028

11. Vagapov R.K., Ibatullin K.A., Zapevalov D.N. Corrosion processes on steel under conditions of moisture condensation and in the presence of carbon dioxide. Chemical and Petroleum Engineering. 2020, vol. 56, no. 7-8, pp. 673-680. http://doi.org/10.1007/s10556-020-00825-5

12. Zapevalov D., Vagapov R. Aspects of protection against carbon dioxide corrosion of gas production facilities. E3S Web of Conferences. 2019, vol. 121, article 02013.

https://doi.org/10.1051/e3sconf/201912102013

13. Singer M. Study of the localized nature of top of the line corrosion in sweet environment. CORROSION. 2017, vol. 73, no. 8 . pp. 1030-1055. https://doi.org/10.5006/2222

14. Vagapov R. Top-of-line corrosion in the presence of carbon dioxide for gas production facilities. E3S Web of Conferences. 2021, vol. 225, article 01002. https://doi.org/10.1051/e3sconf/202122501002

15. Vagapov R.K., Zapevalov D.N., Ibatullin K.A. Study of corrosion of gas production infrastructure objects at presence of $\mathrm{CO}_{2}$ by the methods of analytical control. Zavodskaya laboratoriya. Diagnostika materialov. 2020, no. 10, pp. 23-30. (In Russ.).

16. Jiang X., Qu D., Song X., Liu X., ZhangY. Critical water content for corrosion of X65 mild steel in gaseous, liquid and supercritical $\mathrm{CO}_{2}$ stream. International Journal of Greenhouse Gas Control. 2019, vol. 85, pp. 11-22. https://doi.org/10.1016/j.ijggc. 2019.03.020

17. Sim S., Cole I.S., Bocher F., Corrigan P., Gamage R.P., Ukwattage N., Birbilis N. Investigating the effect of salt and acid impurities in supercritical $\mathrm{CO}_{2}$ as relevant to the corrosion of carbon capture and storage pipelines. International Journal of Greenhouse Gas Control. 2013, vol. 17, pp. 534-541. https://doi.org/10.1016/j.jiggc.2013.06.013

18. Kumar S., Foroozesh J., Edlmann K., Rezk M.G., Lim C.Y. A comprehensive review of value-added $\mathrm{CO}_{2}$ sequestration in subsurface дов на газовых и газоконденсатных месторождениях // Безопасность труда в промышленности. 2021. № 2. С. 56-62.

3. Yaro A.S., Abdul-Khalik K.R., Khadom A.A. Effect of $\mathrm{CO}_{2}$ corrosion behavior of mild steel in oilfield produced water // Journal of Loss Prevention in the Process Industries. 2015. Vol. 38. P. 24-38. https://doi.org/10.1016/j.jlp.2015.08.003

4. Асланян А.М., Асланян И.Ю., Кантюков Р.Р. и др. Внедрение инновационного программно-аппаратного комплекса пассивной акустики для диагностики технического состояния скважин // Безопасность труда в промышленности. 2020. № 11. C. $56-62$.

5. Рязанцев М.В., Лозин Е.В. $\mathrm{CO}_{2}$-воздействие: из истории мировых и отечественных исследований // Нефтяное хозяйство. 2020. № 7. C. 100-103.

https://doi.org/10.24887/0028-2448-2020-7-100-103

6. Ильинова А.А., Ромашева Н.В., Стройков Г.А. Перспективы и общественные эффекты проектов секвестрации и использования углекислого газа // Записки Горного института. 2020. Т. 244. C. 493-502.

7. Хан С.А. Анализ мировых проектов по захоронению углекислого газа // Георесурсы. 2010. № 4 (36). С. 55-62.

8. Onyebuchi V.E., Kolios A., Hanak D.P., etc. A systematic review of key challenges of $\mathrm{CO}_{2}$ transport via pipelines // Renewable and Sustainable Energy Reviews. 2018. Vol. 81. Part 2. P. 2563-2583. https://doi.org/10.1016/j.rser.2017.06.064

9. He M., Luis S., Rita S., Ana G., Eurípedes V.Jr., Zhang N. Risk assessment of $\mathrm{CO}_{2}$ injection processes and storage in carboniferous formations: A review // Journal of Rock Mechanics and Geotechnical Engineering. 2011. Vol. 3. No. 1. P. 39-56. https://doi.org/10.3724/SP.J.1235.2011.00039

10. Choi Y.-S., Young D., Srdjan Nešić, Gray L.G.S. Wellbore integrity and corrosion of carbon steel in $\mathrm{CO}_{2}$ geologic storage environments: A literature review // International Journal of Greenhouse Gas Control. 2013. Vol. 16S. P. S70-S77. https://doi.org/10.1016/j.ijggc.2012.12.028

11. Vagapov R.K., Ibatullin K.A., Zapevalov D.N. Corrosion processes on steel under conditions of moisture condensation and in the presence of carbon dioxide // Chemical and Petroleum Engineering. 2020. Vol. 56. No. 7-8. P. 673-680. http://doi.org/10.1007/s10556-020-00825-5

12. Zapevalov D., Vagapov R. Aspects of protection against carbon dioxide corrosion of gas production facilities // E3S Web of Conferences. 2019. Vol. 121. Article 02013. https://doi.org/10.1051/e3sconf/201912102013

13. Singer M. Study of the localized nature of top of the line corrosion in sweet environment // CORROSION. 2017. Vol. 73. No. 8. P. 1030-1055. https://doi.org/10.5006/2222

14. Vagapov R. Top-of-line corrosion in the presence of carbon dioxide for gas production facilities // E3S Web of Conferences. 2021. Vol. 225. Article 01002. https://doi.org/10.1051/e3sconf/202122501002

15. Вагапов Р.К., Запевалов Д.Н., Ибатуллин К.А. Исследование коррозии объектов инфраструктуры газодобычи в присутствии $\mathrm{CO}_{2}$ аналитическими методами контроля // Заводская лаборатория. Диагностика материалов. 2020. № 10. С. 23-30.

16. Jiang X., Qu D., Song X., Liu X., Zhang Y. Critical water content for corrosion of X65 mild steel in gaseous, liquid and supercritical $\mathrm{CO}_{2}$ stream // International Journal of Greenhouse Gas Control. 2019. Vol. 85. P. 11-22. https://doi.org/10.1016/j.ijggc. 2019.03.020

17. Sim S., Cole I.S., Bocher F., Corrigan P., Gamage R.P., Ukwattage N., Birbilis N. Investigating the effect of salt and acid impurities in supercritical $\mathrm{CO}_{2}$ as relevant to the corrosion of carbon capture and storage pipelines // International Journal of Greenhouse Gas Control. 2013. Vol. 17. P. 534-541. https://doi.org/10.1016/j.ijggc. 2013.06.013

18. Kumar S., Foroozesh J., Edlmann K., Rezk M.G., Lim C.Y. A comprehensive review of value-added $\mathrm{CO}_{2}$ sequestration in subsurface 
saline aquifers. Journal of Natural Gas Science and Engineering. 2020, vol. 81, article 103437.

https://doi.org/10.1016/j.jngse.2020.103437

19. Hua Y., Shamsa A., Barker R., Neville A. Protectiveness, morphology and composition of corrosion products formed on carbon steel in the presence of $\mathrm{Cl}^{-}, \mathrm{Ca}^{2+}$ and $\mathrm{Mg}^{2+}$ in high pressure $\mathrm{CO}_{2}$ environments. Applied Surface Science. 2018, vol. 455, pp. 667-682. https://doi.org/10.1016/j.apsusc. 2018.05.140

20. Tavares L.M., da Costa E.M., de Oliveira Andrade J.J., Hubler R., Huet B. Effect of calcium carbonate on low carbon steel corrosion behavior in saline $\mathrm{CO}_{2}$ high pressure environments. Applied Surface Science. 2015, vol. 359, pp. 143-152. https://doi.org/10.1016/j.apsusc. 2015.10.075

21. Cabrini M., Lorenzi S., Pastore T., Radaelli M. Corrosion rate of high $\mathrm{CO}_{2}$ pressure pipeline steel for carbon capture transport and storage. La Metallurgia Italiana. 2014, vol. 106, no. 6, pp. 21-27.

22. Hua Y., Barker R., Neville A. Effect of temperature on the critical water content for general and localised corrosion of X65 carbon steel in the transport of supercritical $\mathrm{CO}_{2}$. International Journal of Greenhouse Gas Control. 2014, vol. 31, pp. 48-60. http://dx.doi.org/10.1016/j.ijggc.2014.09.026

23. Silva S.C., Silva A.B., Ponciano Gomes J.A.C. Hydrogen embrittlement of API $5 \mathrm{~L}$ X65 pipeline steel in $\mathrm{CO}_{2}$ containing low $\mathrm{H}_{2} \mathrm{~S}$ concentration environment. Engineering Failure Analysis. 2021, vol. 120, article 105081. https://doi.org/10.1016/j.engfailanal.2020.105081

24. Hua Y., Jonnalagadda R., Zhang L., Neville A., Barker R. Assessment of general and localized corrosion behavior of X65 and $13 \mathrm{Cr}$ steels in water-saturated supercritical $\mathrm{CO}_{2}$ environments with $\mathrm{SO}_{2} / \mathrm{O}_{2}$. International Journal of Greenhouse Gas Control. 2017, vol. 64, pp. 126-136. https://doi.org/10.1016/j.ijggc.2017.07.012

25. Zhang Y., Meng Y., Ju X., Jiang Z., Ma Z. Steel corrosion under supercritical carbon dioxide condition with Impurities. Material Performance. 2019, vol. 58, no. 12, pp. 40-43.

26. Zhang Y., Gao K. Inhibiting steel corrosion in aqueous supercritical $\mathrm{CO}_{2}$ condition. Material Performance. 2011, vol. 50, no. 9, pp. 54-59.

27. Xiang Y., Song C., Li C., Yao E., Yanc W. Characterization of $13 \mathrm{Cr}$ steel corrosion in simulated EOR-CCUS environment with flue gas impurities. Renewable and Sustainable Energy Reviews. 2020, vol. 140, pp. 124-136. https://doi.org/10.1016/.psep.2020.04.051

28. Cui G., Yang Z., Liu J., Li Z. A comprehensive review of metal corrosion in a supercritical $\mathrm{CO}_{2}$ environment. International Journal of Greenhouse Gas Control. 2019, vol. 90, article 102814.

https://doi.org/10.1016/j.ijggc.2019.102814

29. Choi Y.-S., Hassani S., Nam Vu.T., Nesic S., Abas A.Z., Nor A.M., Suhor M.F. Corrosion inhibition of pipeline steels under supercritical $\mathrm{CO}_{2}$ environment. NACE - Corrosion Conference Series. 2017, vol. 4, pp. 2734-2745.

30. Chen L., Obeyesekere N., Wylde J. Lab performance testing on corrosion inhibitors under supercritical carbon dioxide conditions. NACE - Corrosion Conference Series. 2017, vol. 4, pp. 2774-2786.

31. Morks M.F., Corrigan P.A., Cole I.S. Mn-Mg based zinc phosphate and vanadate for corrosion inhibition of steel pipelines transport of $\mathrm{CO}_{2}$ rich fluids. International Journal of Greenhouse Gas Control. 2012, vol. 7, pp. 218-224.

https://doi.org/10.1016/j.ijggc.2011.10.005

32. Tanga R., Joshic G.R., Zhaoa H., Venkateswaran S.P., Withersa P.J., Xiao P. The influence of electrodeposited Ni-Co alloy coating microstructure on $\mathrm{CO}_{2}$ corrosion resistance on X65 steel. Corrosion Science. 2020, vol. 167, article 108485. https://doi.org/10.1016/j.corsci.2020.108485 saline aquifers // Journal of Natural Gas Science and Engineering. 2020. Vol. 81. Article 103437.

https://doi.org/10.1016/j.jngse.2020.103437

19. Hua Y., Shamsa A., Barker R., Neville A. Protectiveness, morphology and composition of corrosion products formed on carbon steel in the presence of $\mathrm{Cl}^{-}, \mathrm{Ca}^{2+}$ and $\mathrm{Mg}^{2+}$ in high pressure $\mathrm{CO}_{2}$ environments // Applied Surface Science. 2018. Vol. 455. P. 667-682. https://doi.org/10.1016/j.apsusc. 2018.05.140

20. Tavares L.M., da Costa E.M., de Oliveira Andrade J.J., Hubler R., Huet B. Effect of calcium carbonate on low carbon steel corrosion behavior in saline $\mathrm{CO}_{2}$ high pressure environments // Applied Surface Science. 2015. Vol. 359. P. 143-152. https://doi.org/10.1016/j.apsusc.2015.10.075

21. Cabrini M., Lorenzi S., Pastore T., Radaelli M. Corrosion rate of high $\mathrm{CO}_{2}$ pressure pipeline steel for carbon capture transport and storage // La Metallurgia Italiana. 2014. Vol. 106. No. 6. P. 21-27.

22. Hua Y., Barker R., Neville A. Effect of temperature on the critical water content for general and localised corrosion of X65 carbon steel in the transport of supercritical $\mathrm{CO}_{2} / /$ International Journal of Greenhouse Gas Control. 2014. Vol. 31. P. 48-60. http://dx.doi.org/10.1016/j.ijggc.2014.09.026

23. Silva S.C., Silva A.B., Ponciano Gomes J.A.C. Hydrogen embrittlement of API $5 \mathrm{~L}$ X65 pipeline steel in $\mathrm{CO}_{2}$ containing low $\mathrm{H}_{2} \mathrm{~S}$ concentration environment // Engineering Failure Analysis. 2021. Vol. 120. Article 105081. https://doi.org/10.1016/j.engfailanal.2020.105081

24. Hua Y., Jonnalagadda R., Zhang L., Neville A., Barker R. Assessment of general and localized corrosion behavior of X65 and $13 \mathrm{Cr}$ steels in water-saturated supercritical $\mathrm{CO}_{2}$ environments with $\mathrm{SO}_{2} / \mathrm{O}_{2} / /$ International Journal of Greenhouse Gas Control. 2017. Vol. 64. P. 126-136. https://doi.org/10.1016/j.ijggc.2017.07.012

25. Zhang Y., Meng Y., Ju X., Jiang Z., Ma Z. Steel corrosion under supercritical carbon dioxide condition with Impurities // Material Performance. 2019. Vol. 58. No. 12. P. 40-43.

26. Zhang Y., Gao K. Inhibiting steel corrosion in aqueous supercritical $\mathrm{CO}_{2}$ condition // Material Performance. 2011. Vol. 50. No. 9. P. 54-59.

27. Xiang Y., Song C., Li C., Yao E., Yanc W. Characterization of $13 \mathrm{Cr}$ steel corrosion in simulated EOR-CCUS environment with flue gas impurities // Renewable and Sustainable Energy Reviews. 2020. Vol. 140. P. 124-136. https://doi.org/10.1016/j.psep.2020.04.051

28. Cui G., Yang Z., Liu J., Li Z. A comprehensive review of metal corrosion in a supercritical $\mathrm{CO}_{2}$ environment // International Journal of Greenhouse Gas Control. 2019. Vol. 90. Article 102814. https://doi.org/10.1016/j.ijggc.2019.102814

29. Choi Y.-S., Hassani S., Nam Vu.T., Nesic S., Abas A.Z., Nor A.M., Suhor M.F. Corrosion inhibition of pipeline steels under supercritical $\mathrm{CO}_{2}$ environment // NACE - Corrosion Conference Series. 2017. Vol. 4. P. 2734-2745.

30. Chen L., Obeyesekere N., Wylde J. Lab performance testing on corrosion inhibitors under supercritical carbon dioxide conditions // NACE - Corrosion Conference Series. 2017. Vol. 4. P. 2773-2786.

31. Morks M.F., Corrigan P.A., Cole I.S. Mn-Mg based zinc phosphate and vanadate for corrosion inhibition of steel pipelines transport of $\mathrm{CO}_{2}$ rich fluids // International Journal of Greenhouse Gas Control. 2012. Vol. 7. P. 218-224.

https://doi.org/10.1016/j.ijggc.2011.10.005

32. Tanga R., Joshic G.R., Zhaoa H., Venkateswaran S.P., Withersa P.J., Xiao P. The influence of electrodeposited Ni-Co alloy coating microstructure on $\mathrm{CO}_{2}$ corrosion resistance on X65 steel // Corrosion Science. 2020. Vol. 167. Article 108485. https://doi.org/10.1016/j.corsci.2020.108485 
Izvestiya. Ferrous Metallurgy. 2021, vol. 64, no. 11, pp. 793-801.

\section{INFORMATION ABOUT THE AUTHORS СBEДЕНИЯ ОБ АBTOPAX}

Rafael' R. Kantyukov, Cand. Sci. (Eng.), Deputy General Director for Research, Scientific-Research Institute of Natural Gases and Gas Technologies - "Gazprom VNIIGAZ"

ORCID: 0000-0003-3339-4774

E-mail: vniigaz@vniigaz.gazprom.ru

Dmitrii N. Zapevalov, Cand. Sci. (Eng.), Head of the Corporate Scientific and Technical Center for Corrosion Monitoring and Protection, Scientific-Research Institute of Natural Gases and Gas Technologies - "Gazprom VNIIGAZ"

ORCID: 0000-0002-2867-1995

E-mail: D_Zapevalov@vniigaz.gazprom.ru

Ruslan K. Vagapov, Cand. Sci. (Chem.), Head of the Laboratory of Atmo spheric and Internal Corrosion Protection, Scientific-Research Institute of Natural Gases and Gas Technologies - "Gazprom VNIIGAZ" ORCID: 0000-0002-8467-4103

E-mail: R_Vagapov@vniigaz.gazprom.ru
Рафаэль Рафкатович Кантюков, к.т.н., заместитель генерального директора по науке, Научно-исследовательский институт природных газов и газовых технологий - Газпром ВНИИГАЗ ORCID: 0000-0003-3339-4774

E-mail: vniigaz@vniigaz.gazprom.ru

Дмитрий Николаевич Запевалов, к.т.н., начальник Корпоративного научно-технического центра коррозионного мониторинга и защиты от коррозии, Научно-исследовательский институт природных газов и газовых технологий - Газпром ВНИИГАЗ ORCID: 0000-0002-2867-1995

E-mail: D_Zapevalov@vniigaz.gazprom.ru

Руслан Кизитович Вагапов, к.х.н., начальник лаборатории защиты от атмосферной и внутренней коррозии, Научно-исследовательский институт природных газов и газовых технологий - Газпром ВНИИГАЗ

ORCID: 0000-0002-8467-4103

E-mail: R_Vagapov@vniigaz.gazprom.ru

\section{CONTRIBUTIONS OF THE AUTHORS:}

R.R. Kantyukov - formation of the article concept, goals and objectives of the study, correction of conclusions.

D.N. Zapevalov - scientific guidance, revision and correction of the text, formation of conclusions.

R.K. Vagapov - analysis of research results, text formation, search and analysis of literature data, text formatting and design.

Received 16.04.2021

Revised 18.09.202

Accepted 29.10.2021
Поступила в редакцию 16.04 .2021

После доработки 18.09.2021

Принята к публикации 29.10.2021 